sche Situation bezüglich des Zusammenhangs von Spinorkalkül und Bispinorkalkül hinsichtlich unserer Thematik aufzuklären. Außerdem ergaben sich Bedingungen, unter welchen der Diracsche $\gamma$-Apparat in krummlinigen Koordinaten so formulierbar ist, daß gewissen Hermezitätsforderungen entspro- chen werden kann. Schließlich konnte der Weg genau verfolgt werden, wie sich die Axiomatik der Pauli-Matrizen in Galiler-Koordinaten in den großen Rahmen einfügt.

Herrn Notтroтt danke ich für Kontrollrechnungen.

\title{
NOTIZEN
}

\section{On the $\mathrm{C}-\mathrm{N}$ Stretching Frequencies in para-Substituted Anilines}

By Peter J. Krueger

Department of Chemistry, University of Alberta, Calgary, Alberta, Canada

(Z. Naturforschg. 17 a, 692 - 693 [1962] ; eingegangen am 18. Juni 1962)

Many authors have shown that the stretching frequencies, the absorption intensities, and in some cases the band widths arising from vibrations localized in functional groups attached to an aromatic ring can be related to the electronic nature of the ring substituents through the Hammetr substituent constants $(\sigma)^{1}$ based on chemical reactivity studies. Such correlations have been published for the $\mathrm{OH}$ stretching vibration in phenols ${ }^{2}$, the $\mathrm{C} \equiv \mathrm{N}$ stretching vibration in benzonitriles ${ }^{3-5}$, the $-\mathrm{NH}$ stretching vibration in N-methyl anilines ${ }^{6}$, the $\mathrm{NH}_{2}$ stretching vibrations in anilines ${ }^{5-8}$, and the $\mathrm{C}=\mathrm{O}$ stretching vibration in benzaldehydes ${ }^{9}$, ethyl benzoates ${ }^{9}$ and acetophenones ${ }^{9,10}$. BRown ${ }^{11}$ has shown that in some cases such correlations are more appropriately made in terms of the electrophilic substituent constants $\sigma^{+} 12$. The high precision and accuracy of the recent infrared measurements in this field has justified a statistical treatment of the data by $R_{A O}$ and Venkataraghavan ${ }^{13}$.

1 L. P. Hammetr, Physical Organic Chemistry, McGrawHill, New York 1940, pp. 186 ff. Also see H. H. JAFFE, Chem. Rev. 53, 191 [1953].

2 P. J. Stone and H. W. Thompson, Spectrochimica Acta 10 , 17 [1957].

3 H. W. Thompson and G. Steel, Trans. Faraday Soc. 52. 1451 [1956].

${ }^{4}$ M. F. A. E. SAYED, J. Inorg. Nucl. Chem. 10, 168 [1959].

5 P. J. Krueger and H. W. Thompson, Proc. Roy. Soc., Lond. A 250, 22 [1959].

6 P. J. Krueger and H. W. Thompson, Proc. Roy. Soc., Lond. A 243, 143 [1957].

7 M. S. C. FLETT, Trans. Faraday Soc. 44, 767 [1948].

8 S. Califano and R. Moccia, Gazz. Chim. Ital. 86, 1014 [1956].

9 H. W. Thompson, R. W. Needham and D. Jameson, Spectrochimica Acta 9, 208 [1957].

10 R. N. Jones, W. F. Forbes and W. A. Mueller, Canad. J. Chem. 35, 504 [1957].
Although such relations have contributed to our understanding of the structure and behaviour of organic molecules, they have remained largely empirical since completely satisfactory theoretical calculations of the substituent constants have not yet been made ${ }^{14}$. However, Brown ${ }^{15}$ has shown, on the basis of a simple molecular orbital treatment, that such correlations of spectroscopic parameters with essentially kinetic constants are reasonable, since the changes in electron distribution which occur in the molecule during vibrational distortions closely parallel those which occur in the formation of the transition state during chemical reactions.

These correlations have also been shown to hold in such cases where the vibration involves one of the aromatic ring carbon atoms, as in the asymmetrical $\mathrm{C}-\mathrm{O}-\mathrm{C}$ stretching vibration in anisoles ${ }^{16}$. More recently RitschL ${ }^{17}$ has extended this to a simpler vibrational mode, the $\mathrm{C}-\mathrm{N}$ stretching vibration in parasubstituted anilines, where the frequency rises as the ring substituents become more electron withdrawing.

Since no interpretation was offered for this behaviour of the $\mathrm{C}-\mathrm{N}$ stretching frequency, and since the $\mathrm{NH}_{2}$ stretching vibrations in substituted anilines have been studied in great detail ${ }^{18,19}$, it has now been possible to justify these results in a more fundamental manner. The HNH bond angle calculated from the $\mathrm{NH}_{2}$ stretch-

11 T. L. Brown, J. Amer. Chem. Soc. 80, 794 [1958].

12 H. C. Brown and Y. Oкамото, J. Amer. Chem. Soc. 79, 1913 [1957]; J. Org. Chem 22, 485 [1957].

13 C. N. R. Rao and R. Venkataraghavan, Canad. J. Chem. 39, 1757 [1961].

14 G. W. Wheland, Advanced Organic Chemistry, 3rd edition, John Wiley \& Sons, New York 1960, p. 535.

15 T. L. Brown, J. Phys. Chem. 64, 1798 [1960].

16 G. K. Goldman, H. Lehman and C. N. R. Rao, Canad. J. Chem. 38, 171 [1960].

17 F. Ritschl, Z. Chem. 1, 285 [1961].

18 P. J. Krueger, D. Phil. Thesis, Oxford University 1958.

19 P. J. Krueger, Comparative measurements on the fundamental and first overtone $\mathrm{NH}_{2}$ stretching vibrations in dilute carbon tetrachloride solution for more than 60 ortho-, meta- and para-substituted anilines. To be published shortly. 
ing frequencies ${ }^{20}$ increases smoothly from $109.4^{\circ}$ in $p$-phenylenediamine to $111.1^{\circ}$ in aniline to $113.6^{\circ}$ in $p$-nitroaniline, as the nitrogen atom changes from almost pure $\mathbf{s p}^{3}$ hybridization towards a state with a higher $s / p$ ratio as the lone pair electrons are progressively delocalized over the aromatic ring. This increase in s-character is reflected in an increase in the $\mathrm{NH}_{2}$ stretching frequencies, accompanied by a rise in the $\mathrm{C}-\mathrm{N}$ stretching frequencies as this bond acquires more double bond character.

Quantitatively the constant $b$, which is the coefficient of the 2 s-orbital of nitrogen in the hybrid ${ }^{20}$

$$
\psi_{\text {'hybrid }}=b \psi_{2 \mathrm{~s}}+\sqrt{\left(1-b^{2}\right)} \cdot \psi_{2 \mathrm{p}}
$$

can be used as a measure of s-character of the hybrid nitrogen orbitals binding the hydrogen atoms. This coefficient can be calculated from the expression

$$
b^{2}=-\cos \Theta /(1-\cos \Theta)
$$

where $\Theta$ is the $\mathrm{HNH}$ angle. These results are tabulated in Table 1 . Since $b$ and the double-bond character of the $\mathrm{C}-\mathrm{N}$ bond increase together as the substituent groups become more electron-withdrawing, a linear relationship between the $\mathrm{C}-\mathrm{N}$ stretching force constant and $b$ might be expected. In this closely related series of molecules this force constant should be proportional to the square of the corresponding stretching frequency. Fig. 1 shows that this linear dependence is observed.

20 S. F. Mason, J. Chem. Soc. 1958, 3619; see also J. W. Linnetr, Trans. Faraday Soc. 41, 223 [1945].

\section{Die Bildung von Cyclohexadienylradikalen durch Anlagerung von Wasserstoffatomen an festes Benzol}

\author{
Von H. Fischer
}

Deutsches Kunststoff-Institut, Darmstadt

(Z. Naturforschg. 17 a, 693-694 [1962] ; eingegangen am 27. Juni 1962)

In einer vorangehenden Arbeit ${ }^{1}$ wurde das Elektronenspinresonanz(ESR)-Spektrum des bei $77^{\circ} \mathrm{K}$ bestrahlten Benzols durch das Cyclohexadienylradikal interpretiert, das durch Anlagerung eines Wasserstoffatoms an den aromatischen Ring entsteht. Diese Interpretation ist auch von anderen Autoren ${ }^{2}$ unabhängig von uns vorgeschlagen worden. Sie konnte weiterhin durch die Berechnung der Spindichtenverteilung des Radikals gestützt werden ${ }^{3}$, die gute Übereinstimmung zwischen dem Spektrum entnommenen „experimentellen“ und „theoretischen“ Werten ergab.

1 H. Fischer, Kolloid-Z. 180, 64 [1962].

2 W. A. Tolkatschev, Y. N. Molin, J. J. Chkeidze, N. Y. Buben u. V. V. Voevodskis, Ber. Akad. Wiss. UdSSR 141, 911 [1961].

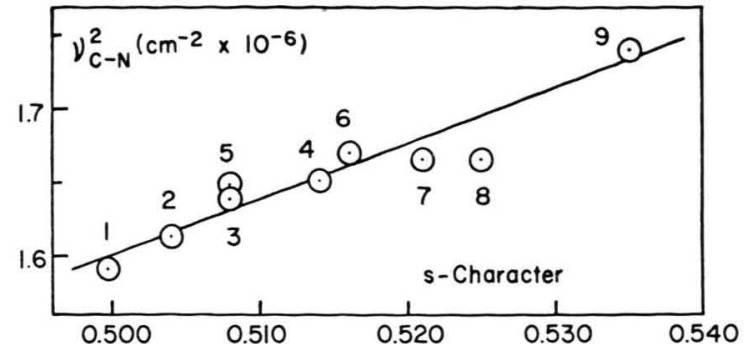

Fig. 1. Relationship of the $\mathrm{C}-\mathrm{N}$ stretching force constant in para-substituted anilines, as measured by the square of the corresponding stretching frequency, to the s-character of the hybrid nitrogen orbitals binding the hydrogen atoms. The abscissa axis also reflects an increase in the double-bond character of the $\mathrm{C}-\mathrm{N}$ bond.

\begin{tabular}{|l|l|c|c|c|}
\hline No. & Substituent & $\begin{array}{c}\mathrm{C}-\mathrm{N} \text { Stretching } \\
\text { Frequency }\left(\mathrm{cm}^{-1}\right)^{\mathrm{a}}\end{array}$ & s-Character $\mathrm{b}$ & $\begin{array}{c}\mathrm{HNH} \text { Angle } \\
\left({ }^{\circ}\right)^{\mathrm{c}}\end{array}$ \\
\hline 1 & $p-\mathrm{NH}_{2}-$ & 1261 & 0.499 & 109.4 \\
2 & $p-\mathrm{CH}_{3} \mathrm{O}-$ & 1270 & 0.504 & 109.9 \\
3 & $p-\mathrm{CH}_{3}-$ & 1280 & 0.508 & 110.3 \\
4 & $\mathrm{H}-$ & 1285 & 0.514 & 111.1 \\
5 & $p-\mathrm{F}-$ & 1284 & 0.508 & 110.3 \\
6 & $p-\mathrm{Cl}-$ & 1292 & 0.516 & 111.3 \\
7 & $p-\mathrm{Br}-$ & 1290 & 0.521 & 111.8 \\
8 & $p-\mathrm{I}^{-}$ & 1290 & 0.525 & 112.4 \\
9 & $p-\mathrm{NO}_{2-}$ & 1319 & 0.535 & 113.6 \\
\hline
\end{tabular}

according to RirschL ${ }^{17}$; measurements in tetrahydrofuran.

b calculated from equations (1) and (2), and equal to 0.500 for an $\mathrm{sp}^{3}$ hybrid orbital.

c calculated from the symmetric and asymmetric $\mathrm{NH}_{2}$ stretching frequencies according to LINNETT ${ }^{20}$.

Table 1. The $\mathrm{C}-\mathrm{N}$ Stretching Frequencies in para-Substituted Anilines.

Aus der Literatur ${ }^{4}$ ist nun bekannt, daß durch Anlagerung von Wasserstoffatomen an aromatische Verbindungen hydrierte Ringsysteme gebildet werden. Wenn diese Hydrierung nach einem Radikalmechanis. mus abläuft, sollten insbesondere bei Benzol Cyclohexadienylradikale als instabile Zwischenprodukte auftreten, die durch ESR-Untersuchungen nachgewiesen

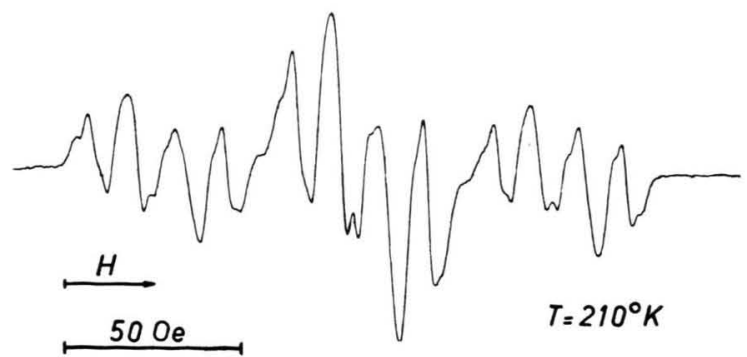

Abb. 1. ESR-Spektrum von Produkten der Reaktion zwischen Wasserstoffatomen und festem Benzol. Meßtemperatur $210^{\circ} \mathrm{K}$.

${ }^{3}$ H. Fischer, Z. Naturforschg. 17 a, 354 [1962] ; J. Chem. Phys., im Druck.

${ }^{4}$ K. H. Geib u. P. Harteck, Chem. Ber. 66, 1815 [1933]. 